\title{
Developmental Dyslexia vs. Japanese Writing Systems' Neuronal Processing
}

\section{Dysleksja rozwojowa a neuronalne procesy przetwarzania pisma japońskiego}

\author{
Patrycja Dyszy-Chudzińska \\ INSTYTUT JĘZYKOZNAWSTWA, UNIWERSYTET IM. ADAMA MiCKIEWICZA \\ AL. NIEPODLEGŁOŚCI 4, 61-874 POZNAŃ \\ pdyszy@gmail.com
}

\begin{abstract}
This paper is an attempt to explain the neuronal processes engaged in Japanese writing systems processing and its role in developmental dyslexia ${ }^{1}$ in the Japanese language. It deals with the question of the hemispheric processing in the Japanese language and explains the mechanisms of developmental dyslexia in the language under discussion. The processes of reading and writing in Japanese will also be presented as they are crucial to a more in-depth understanding of the condition of developmental dyslexia in the Japanese language.
\end{abstract}

\section{The Individual Characteristics of Japanese Writing Systems}

Japan has four different writing systems used on a regular basis: two syllabaries - hiragana and katakana (collectively termed kana ${ }^{2}$ ) - kanji ${ }^{3}$

${ }^{1}$ This publication refers to developmental dyslexia only, thus the phrases developmental dyslexia and dyslexia are used alternatively.

${ }^{2}$ Kana is the syllabic Japanese script where one symbol represents one or two mora (Kobayashi et al. 2005). Kana is a purely Japanese invention, having been derived from Kanji. Both the syllabaries consist of 5 vowels, 42 open syllables and the nasal sonorant $n$ (Tubielewicz 1996). Hiragana is used to write native Japanese words, okurigana (inflected verbs and adjective endings) and particles, while katakana is used for the transcription of non-Japanese loanwords and foreign names. Katakana also represents onomatopoeia and is employed in emphatic way - kanji words are written in katakana to emphasise them. Hiragana is used to represent grammatical morphemes (grammatical endings, function words, inflectional endings, postpositions, etc.; Taylor 1987: 142) and words with no direct equivalent in kanji.

3 Kanji have been derived from Chinese pictograms. They are the equivalents of morphemes (Harley 2001) and are used to write parts of the language such as nouns, 
and rōmaji ${ }^{4}$. Because of the specific processing of kana scripts, the reading process is less linked to phoneme processing compared to alphabet-based languages. In Japanese, syllables and onins 5 are more important units than phonemes, therefore syllable manipulation is more significant than phoneme manipulation (Kato 2003). In this language, syllables are rarely segmented into phonemes and onins (Kato 2006). Moreover, tokushu

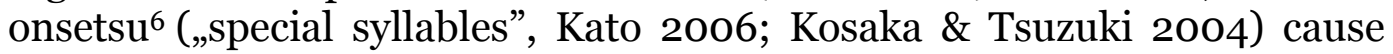
reading problems in children to a similar extent as phonemes and onins. In Japanese, there are 18 phonemes: 13 consonants and 5 vowels. A syllable is formed by combining those elements (Kosaka \& Tsuzuki 2004).

Japanese orthography is syllable-based. The syllable is a basic analytical unit formed according to the V, CV and CSV patterns, where V stands for vowel, $\mathrm{C}$ - consonant and $\mathrm{S}$ - semivowel (Chmielina 2005). The only exceptions to this rule are syllables ending with a nasal coda $\mathrm{n} 7$. According to moraic theory, there are two types of syllables - heavy and light. The former consists of two moras, while the latter of one moras.

Leong and Tamaoka (as cited in Kobayashi et al. 2005) explain that spoken Japanese is a mora-based language, with mora comprising intrasyllabic units of timing 9 and rhythm. Kana characters match moras on

adjective stems and verb stems. There are about 40 thousand kanji in Japan. However, the average Japanese person is obliged to learn jōyo kanji in primary and secondary school. Jōyō kanji is a guide to 1945 kanji characters announced by the Japanese Ministry of Education (http://en.wikipedia.org/wiki/Kanji [accessed: 19.12.2008]). In Japan, the majority of kanji have at least two different sounds (Taylor 1987). One sound is Chinesederived - on-yomi - and it approximates the Chinese reading of kanji. Another one, called kun-yomi, is Japanese-native sound that represents Japanese words for concepts expressed in kanji. Many kanji have a few variants in both kun-yomi and on-yomi. Kanji, in fact, may be very useful, for instance to disambiguate numerous homophones of Japanese origin and Chinese loan words or to make key content words stand out in a text (Taylor 1987: 208).

4 Rōmaji is a Roman alphabet used to write Japanese text. The romanization is used when a text is targeted at those who do not know Japanese, such as for names on street signs and passports, and in dictionaries and textbooks for foreign learners of the language. Rōmaji does not belong in the main stream of research into developmental dyslexia in Japan. Moreover, since rōmaji is processed in the human brain as an alphabetic language, it will not be further referred to here.

5 It's quite complicated hard to give a single definition of the word onin (音韻) as, like many technical linguistics terms, the exact definition varies. It can indicate at least three notions and the way it's used by scientists remains quite equivocal. An onin represents a speech sound distinguishable by an individual. For instance, many Japanese cannot distinguish /l/ from /r/. Physically, these are two separate sounds but they are referred to as an onin if they are not distinguished cognitively. The word cat can be segmented into a phoneme (onso 音素) [k] and an onin at/ (as in the word rat; Kato 2003).

${ }^{6}$ Special syllables contain a diphthong (syllables with „y” in the middle, e.g. kyaku), a double consonant (e.g. gakko), a long vowel (e.g. rōmaji) or a syllable-final n (Kato 2006; Kosaka \& Tsuzuki 2004). They cause reading problems for dyslexic and mentally retarded children (Kato 2006).

${ }_{7}$ Syllable-final $\mathrm{n}$.

8 http://en.wikipedia.org/wiki/ Syllable [accessed: 31.03.2009]

9 Every mora has the same timing (http://en.wikipedia.org/wiki/Mora_(linguistics) [accessed: 05.01.2009]. 


\section{Patrycja Dyszy-Chudzińska: Developmental Dyslexia vs. Japanese Writing Systems' Neuronal Processing}

a one to one basis (Matsuda 2006). A word in Japanese consists of one or a few moras. Phoneme, mora, syllable - the size of the sound unit increases in this order (Kosaka \& Tsuzuki 2004). In some words, the syllable and mora units are the same (Kobayashi et al. 2005). The final part of a long vowel, the syllable-final $\mathrm{n}$ and the double consonant stand for the second mora in heavy syllables (Goswami \& Ziegler 2005: 7; Kosaka \& Tsuzuki 2004: 106). For example, hiragana's とうきょう is written as Tōkyō while katakana’s キャットis written kyatto (cat) using Hepburn’s romanization. Tōkyō and kyatto have two syllables but four (to-o-kyo-o) and three (kya-tto) moras respectively. The timing of the mora units is the same.

Traditionally, Japanese is written vertically, with columns ordered from right to left ${ }^{10}$. However, horizontal writing that reads from left to right $^{11}$ has come into more regular use since the Latin alphabet and Arabic numerals are more often implemented in the Japanese writing system (Taylor 1987). Tategaki is used in school, newspapers and generally in everyday life, whereas yokogaki is regularly used in professional journals and academic publications, where loanwords written in rōmaji appear frequently. The proliferation of computer technology has also contributed to the popularization of the yokogaki format ${ }^{12}$.

\section{The Reading and Writing Process in Japanese}

Because of kana's simplicity, a child can recognize some hiragana characters before he or she goes to school (Kato 2006; Kubota 2003). Hiragana is also typically introduced at home (Kobayashi et al. 2005). Amano (as cited in Kobayashi et al. 2005: 2) reports that, at about 4 years of age, Japanese children start to develop the ability to segment spoken words into syllables and further refine this ability with age. Preferably, children should develop syllable awareness at about 4-5 years of age before they obtain formal reading instruction at school13. Hara (as cited in Kobayashi et al. 2005) reports that there is a rapid growth in phonological analysis skills between kindergarten and the first grade. The National Institute for the Japanese Language 14 (as cited in Kosaka \& Tsuzuki 2004) states that the Ministry of Education guidelines require that hiragana is taught prior to katakana (until the end of first grade summer term, while katakana is taught from the second till the fourth grade). Kanji are introduced systematically, with 1000 kanji taught by the end of the sixth grade. At first reading tuition receives the most attention.

To master reading skills, a child needs to be able to segment words and phrase, intentionally access the mental lexicon and rapidly recognize and retrieve kanji reading from the mental lexicon. Inagaki (as cited in Kobayashi et al. 2005) maintains that preliterate Japanese children

\footnotetext{
${ }^{10} \mathrm{~A}$ format known as tategaki.

${ }^{11} \mathrm{~A}$ format known as yokogaki.

$12 \mathrm{http}: / /$ pl.wikipedia.org/ wiki/Pismo_japońskie [accessed: 15.12.2008]

${ }^{13}$ Education in Japan starts at the age of six.

14国立国語研究所 (Kokuritsu kokugo kenkyūsho).
} 
analyze speech using a mixture of syllable- and mora-based strategies. As they start to learn kana at school, they employ mora-based analysis ${ }^{15}$. Tamaoka and Terao (as cited in Kobayashi et al. 2005) prove that adults appear to apply syllable-based strategies - a kana syllable containing two moras is read aloud as syllable. Endo (as cited in Kobayashi et al. 2003: 259) adds that phonemic processing is formed at about 6-7 years of age. Ito (as cited in Kosaka \& Tsuzuki 2004) claims that the conscious recognition of tokushu onsetsu is not necessary for acquiring reading skills. He noticed that children who cannot consciously recognize 'special syllables' have actual problems reading. However, not all normal readers recognize those syllables consciously.

Uno (as cited in Itani 2001) and Saito (as cited in Kosaka \& Tsuzuki) say that kana is primarily processed phonologically in the reading process, whereas kanji is processed semantically. Kana accesses the mental lexicon via phonological coding. Kanji's coding is determined by its visual pattern. Unlike kana, kanji access the mental lexicon directly via visual information and later it is subject to phonological coding while the visual and auditory memory is referred to. Kanji are mostly processed visually, so a reading process (decoding) as such is not necessary to grasp their meaning. According to Morinaga (as cited in Kosaka \& Tsuzuki 2004), the reading process in Japanese is relatively simple compared to the alphabetical languages. Saccadic eye movements ${ }^{16}$ are rarely observed in the reading process, which may indicate that the eyeballs follow the word level (Kaneko et al. 2003). Phonological awareness proves to be essential in mastering the ability to decode phonograms, including kana (Seki et al. 2008). Language games (reverse reading, reverse repetition, phoneme deletion or pseudoword repetition) are important indicators of developing phonological awareness in children, measuring their readiness to read words and texts (Kato et al. 2005).

The complexity of the writing process differs depending on the writing system. It is most complicated in kanji and the simplest in hiragana, with katakana in the middle. Due to this fact, writing instruction in school is given accordingly (Uno 2003b). A Japanese child has to master few types of scripts, so writing tuition receives increased attention compared to reading tuition, both at school and at home. The Japanese school curriculum allocates disproportionately more time to teach writing. To master writing skills it is crucial to recognize visual symbols and to control the grip on a writing tool (e.g. a pen) and its pressure. A child also has to

\footnotetext{
15 Intrasyllabic analysis.

${ }^{16}$ Simultaneous movements of both eyes in the same direction, serving as a mechanism for fixation (Cassin \& Salomon 1990). Humans do not look at a scene with fixed steadiness - instead, their eyes are in a constant state of vibration, locating interesting parts of the scene and building up a mental image corresponding to the scene. Saccades to an unexpected stimulus normally take about 200 milliseconds (ms) to initiate and then last from about 20-200 $\mathrm{ms}$ depending on their amplitude (20-30 $\mathrm{ms}$ is typical in language reading). During this movement, the human is "blind" as the image is not being cast on to the brain. The impression of constant vision is the effect of brain's operation.
} 


\section{Patrycja Dyszy-Chudzińska: Developmental Dyslexia vs. Japanese Writing Systems' Neuronal Processing}

control the size and shape of the letters. Additionally, one must know the writing rules and formats. To master writing kanji, a child has to be able to follow the following process: recognize the kanji character (which then becomes a pattern), remember it visually, store it in the memory and eventually recall it (Haruhara et al. 2005; Uno et al. 2005). Reading disabilities result in writing problems (Kato 2006).

\section{Neuronal Processes in Japanese Scripts Processing}

In recent years, numerous studies have examined differences in processing various writing systems in the human brain. They prove unanimously that the brain lateralization of script processing is dependant on the type of script. Alphabetic scripts are processed in the left language hemisphere. However the situation is more complex for logographic scripts and this shall be discussed below. Apparently, phonetic scripts 17 and kanji characters are processed differently in human brain. In patients with brain damage, processing both kanji and kana becomes impaired (Taylor 1987).

In the last thirty years, a number of studies have investigated the lateralization of kanji processing. Since there has been no equivocal body of evidence, the matter still arouses controversy. Hatta (as cited in Taylor 1987), the forerunner in this field, noticed that single kanji characters are better processed in the right hemisphere while words consisting of two kanji characters written vertically are more accurately processed in the left hemisphere. This can be explained by the lateralization of brain functions - the right hemisphere processes visual patterns holistically. Researchers hypothesize that kanji accesses the mental lexicon directly - through lexical processing (Haynes 2001). To process a word consisting of at least two kanji characters, sequence processing is required, which remains in the left hemisphere's domain (Taylor 1987; Harley 2001). In subsequent years, several research projects have been conducted to verify Hatta's reports. To some of them (just to mention Sakurai (as cited in Nakamura et al. 2005)), kanji reading triggers left hemispheric processing, while to others (e.g. Sasanuma; as cited in Nakamura et al. 2005) they are processed in the right hemisphere. FMRI 18 studies conducted by Nakamura (2005) showed that logograms act like objects or symbols within the bilateral occipitotemporal cortex (right medial anterior fusiform gyrus), while the leftward-lateralization common to the three types of stimuli - naming logograms, objects and phonograms - only appears during the more global or later processing stages associated with the perisylvian cortex (Nakamura, et al. 2005: 12). Gauthier, Martin and Chao (as cited in Nakamura et al. 2005: 15) argue that the different neuronal clusters of the occipitotemporal area respond to various categories of visual objects, whereas van Turennout (as cited in Nakamura et al. 2005) reminds us that the organization of the brain systems for object naming

17 Here, kana.

18 Functional magnetic resonance. 
changes depending on perceptual experience. Given all that, it seems natural to Nakamura (et al. 2005: 12) that the processing stream of objects, logograms and phonograms is shaped differently in this region. It should also be taken into consideration that phonograms are acquired at an earlier stage of life and are used extremely frequently in everyday life compared to logograms, so normal readers are exposed to these materials to a different degree. These differences might eventually lead to the differential, script-specific organization of the occipitotemporal region (Nakamura et al. 2005: 12).

Kana hemispheric processing is not that controversial. Studies lead by many researchers reported that kana is processed in the left hemisphere. The processing of a single kana word appears to produce left-lateralized activation (Taylor 1987; Harley 2001). Law's (as cited in Price 2002) singular kana word processing test revealed increased activation in the left supramarginal gyrus area located in the front part of the inferior parietal cortex (Brodmann area 40; Price 2002). Nakamura (2005) observed that the phonogram naming test activates the left part of the area around the Sylvian fissure.

\section{Developmental Dyslexia in the Japanese Language}

Until now, developmental dyslexia ${ }^{19}$ has not been defined by law. Therefore the International Dyslexia Association's (IDA; Uno et al. 2006) definition is being referred to. It says that dyslexia is a specific learning disability that is neurological in origin. It is characterized by difficulties with accurate and/or fluent word recognition and by poor spelling and decoding abilities. These difficulties typically result from a deficit in the phonological component of language that is often unexpected in relation to other cognitive abilities and the provision of effective classroom instruction. It cannot be accounted for by any deficit in general intelligence or sensory acuity. Secondary consequences may include problems in reading comprehension and reduced reading experience that can impede the growth of vocabulary and background knowledge' ${ }^{20}$. 'Dyslexia is manifested by variable difficulty with different forms of language, often including, in addition to problems with reading, a conspicuous problem with acquiring proficiency in writing and spelling' (Lyon et al. 2003: 3; Bogdanowicz \& Andryjanek 2004). The above definition is employed in Japan, however the importance of visual processing is emphasised, since it is crucial to the processing of Japanese scripts (Uno et al. 2006).

\footnotetext{
19 In Japan, the nomenclature on developmental dyslexia is not uniform, which especially complicates the revision of professional journals. This probably relates to the fact that developmental dyslexia has not yet been defined by law. It is referred to as dyslexia (adopted from the English), the reading and writing disorder or reading and writing difficulties etc.

${ }^{20}$ http://www.dyslexia-ca.org/dyslexiadefinition.html [accessed: 13.07.009]
} 


\section{Patrycja Dyszy-Chudzińska: Developmental Dyslexia vs. Japanese Writing Systems' Neuronal Processing}

The belief that the problem of developmental dyslexia almost does not exist in Japan ${ }^{21}$ was debunked by Hirose and Hatta's (as cited in Zhang, Popp http://web.wm.edu/education/599/o4projects/Zhang.pdf?svr=www [accessed: 15.04.2009]) study. Up-to-date studies conducted by Uno (as cited in Ishii 2006; Kato 2006) prove that $1 \%$ of children have problems reading in hiragana, 2-3\% - katakana and 5-6\% - kanji, while 2\%, 5\%, 7$9 \%$ of children encounter difficulties in writing hiragana, katakana and kanji respectively. However, Kato has reservations about the accuracy of the results of the reading test run by Uno. She claims that the criteria used in the reading test might have been too narrow, exhibiting a low prevalence of developmental dyslexia in Japan (Kato 2006).

Japanese dyslexic children encounter numerous language difficulties (Kato 2006). In reading, they reverse kana syllables, omit kana characters, syllables, words and even phrases, they also confuse similar kana characters, read slowly, without fluency and "character by character", have difficulties with reading kanji with multiple readings (Kato 2006; Shinagawa 2003) and have to cope with the lack of spaces between words in the text ${ }^{22}$. In writing, dyslexic children do not remember the exact visual pattern of kanji or kana characters, have bad handwriting, confuse characters that have similar visual patterns, misspell or omit elements of characters, whole characters and parts of words and have difficulties in writing from listening or in writing complicated kanji. They also misuse scripts (hiragana and katakana confusion) and face the problem of mirror writing. The speed of visual information recognition and processing appears to be disturbed, as is remembering and recalling language information (Shinagawa 2003). Problems caused by homophony, difficulties in naming objects, abstract name recollection, difficulties in copying pictures and letters, proportional and skilled writing of pictures and other learning problems (especially foreign languages) can also be found. Dyslexic children have a poor vocabulary and a disturbed lateralization process (Kato 2006). The simulation of reading problems that developmental dyslexia might be the cause of, are shown in figure 3.1, while figure 3.2 presents real writing difficulties that dyslexia actually causes.

${ }^{21}$ Makita (1968, as cited in Wydell 1999; 2000) claimed that only $0.1 \%$ of children have problems reading.

22 In Japanese text, only punctuation marks (commas and full stops) are used (Kato 2006). 
$\mathbf{a}$

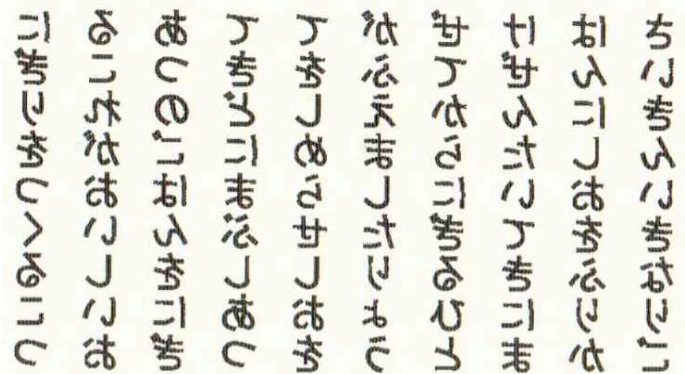

c

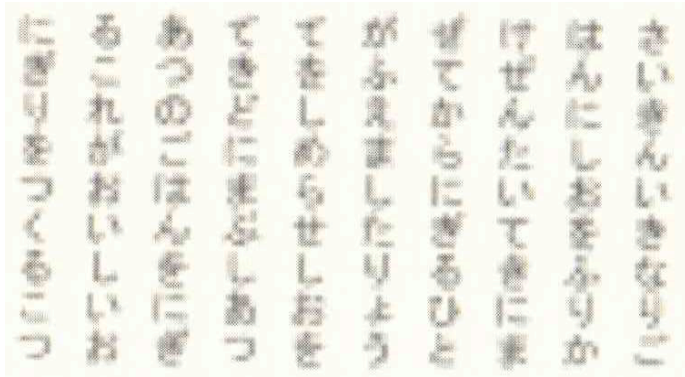

b

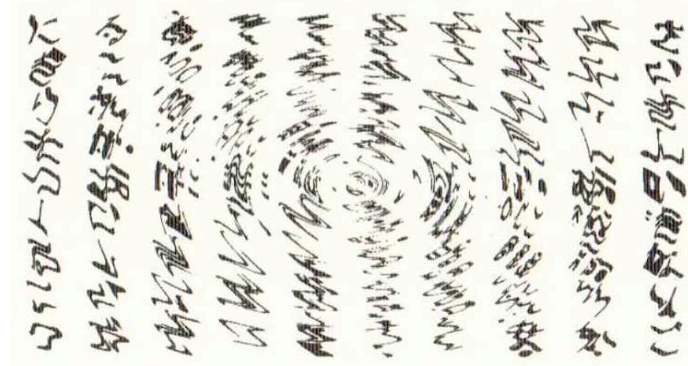

d

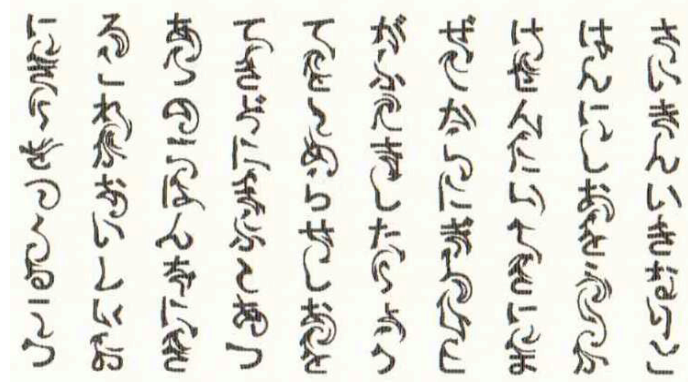

e

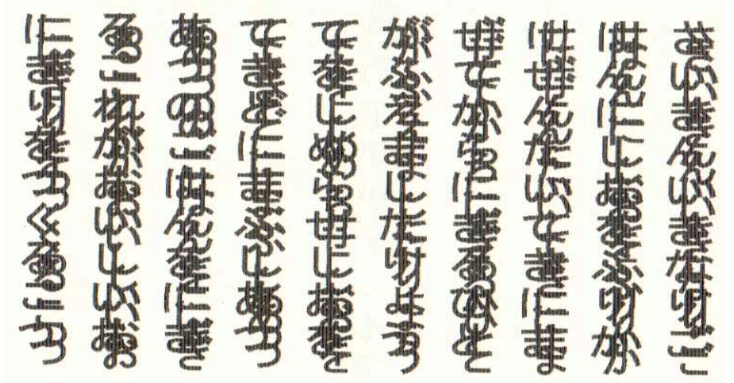

Figure 3.1 The simulation of actual reading difficulties caused by developmental dyslexia. a, Mirror letters. b, Deformed letters. c, Blurred letters. d, Moving letters. e, Overlapping letters. Reprinted from “怠けてな んかない!,” by Shinagawa, Y., 2003. Iwasaki Shoten.

It has also been observed that, in Japanese, unlike in English, reading difficulties are very often accompanied by other cognitive deficits (Wydell 2000). 


\section{Patrycja Dyszy-Chudzińska: Developmental Dyslexia vs. Japanese Writing Systems' Neuronal Processing}

Since Japanese is a syllable-based language, developmental dyslexia is caused by a syllable awareness deficit rather than phoneme awareness deficit. Reading problems are almost always accompanied by writing difficulties. Morinaga and Oishi (as cited in Kobayashi et al. 2005) remind us that kanji causes more reading and writing problems than kana for Japanese children with reading disabilities. Words consisting of complex kanji impede the reading process. Eyeballs movement analysis provides evidence that dyslexic children return to previously read passages of text and, as a result, they require more time to read than regular readers (Kaneko et al. 2003). It is lot easier to read words that are already known and which have regular or only one possible pronunciation (Kato 2003). Children with reading disabilities have a poor vocabulary, a problem which only intensifies over time (Kato 2003). A phonological deficit might reveal the moment that a Japanese child starts to learn English, manifesting itself in a reading disability in English (Kato 1998; Kosaka \& Tsuzuki 2004).

Similarly to other languages, dyslexia cannot be fully overcome in Japanese. It is possible to facilitate the reading process, but mainly using compensatory methods (Oishi 2005). Nonetheless, dysgraphia tends to persist over time (Kato 2003; Shinagawa 2003).

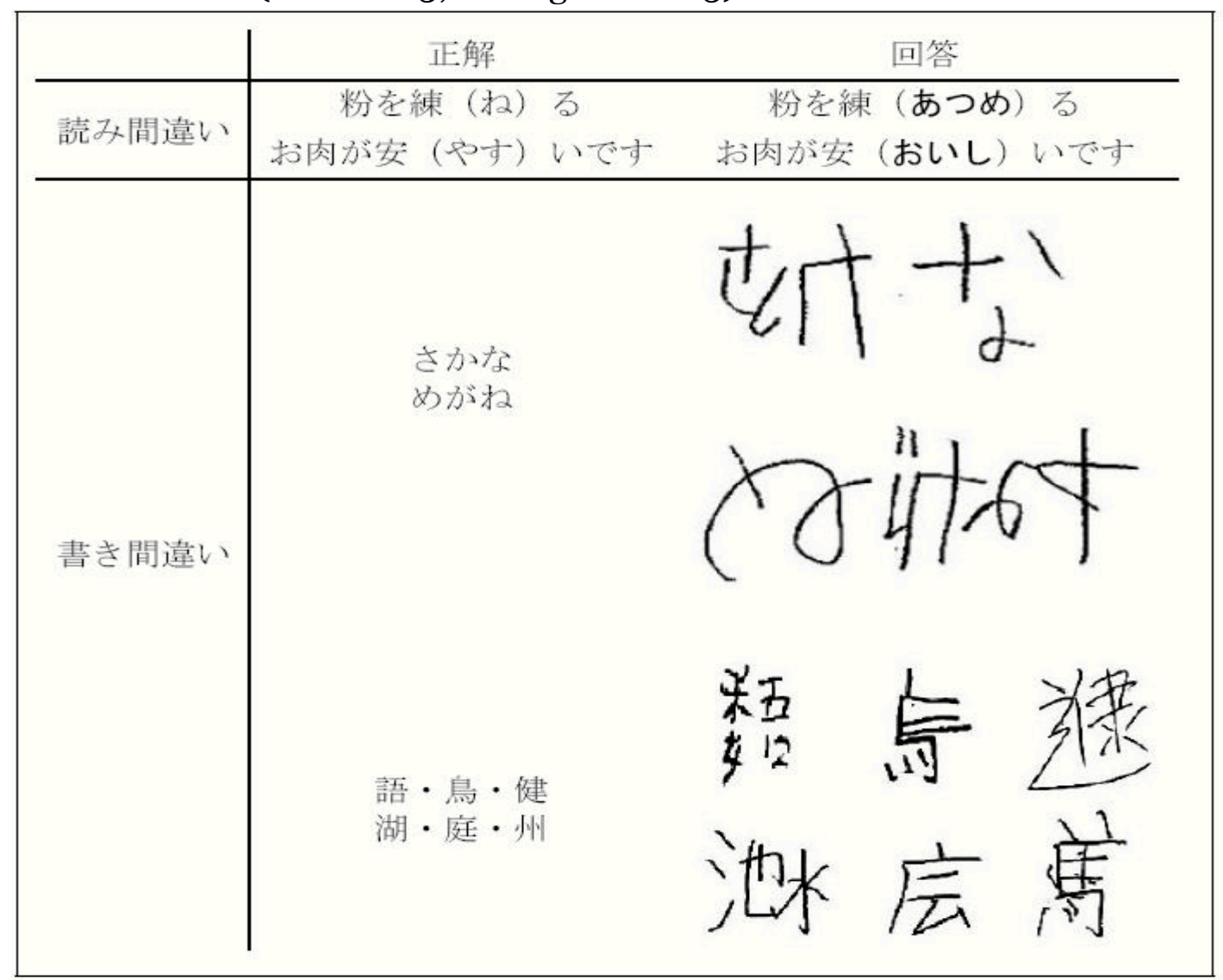

Figure 3.2 Kanji and kana writing difficulties that dyslexic children have to struggle with. Normal handwriting on the left and the disturbed handwriting of a dyslexic child on the right. Reprinted from “読み書きのみ の学習困難 (ディスレキシア) への対応策,” by Ishii, K., 2006, National Institute of Science and Technology Policy, 45(1). 
It happens that, due to variety of writing systems used in Japan, developmental dyslexia manifests itself in various ways depending on the writing system (kana, kanji and alphabet). Few 'types' of developmental dyslexia can be distinguished in Japanese, depending on whether the disorder develops in only one writing system or in more. The disorder may appear in writing and reading simultaneously, due to the neuronal processing of Japanese writing systems (Uno 2006). Diverse scripts are subject to different kinds of processing in the human brain, so it is possible that writing and reading difficulties do not appear jointly in all the writing systems employed in Japan. Uno (2006) distinguished four combinations of reading and writing disabilities:

$>$ reading and writing disorder of hiragana, katakana and kanji,

$>$ reading and writing disorder of katakana and kanji,

$>$ reading and writing disorder of kanji,

$>$ writing disorder of kanji.

Several researches have investigated this matter. Uno (2003a) suggests that, when reading and writing hiragana is disturbed, the reading and writing disorder of katakana and kanji almost always appears. Itani (2001) reports on a child with dyslexia manifesting itself stronger in kanji than kana. To Itani, this can be explained by a failure in the visual to auditory transfer while reading kanji, while the process of recalling kanji's pronunciation via semantic path remains undisturbed. In the kanji writing process, the process of auditory to visual pattern transposition is disturbed - it is difficult to recall the visual pattern of kanji that corresponds to a given sound. Morinaga (as cited in Kobayashi et al. 2005) introduces the case of children who mainly struggle with kanji - children with so called "visual dyslexia" or "decreased visual processing abilities". A limited memory for the details of kanji and reversals of kanji characters in writing has been detected in these children. They did well in phonological analysis test however. Oishi (2001) expects that a character to sound conversion failure might be the reason for phonological dyslexia in kana and kanji. Still, in alphabet's case, the problem might be caused by developmental delays in phonological awareness. Haruhara (2003) deals with children with a deficit in specific developmental semantic processing. She noticed that children have comprehension difficulties, even if the phonological processing is undisturbed. Haruhara supposes that the situation could be explained by independent phonological and semantic processing. RCFB ${ }^{23}$ studies showed a decreased activation in the Wernicke's area. Kato (2006) claims that there exists a type of dyslexia that manifests only when a Japanese person uses an alphabetic languages ${ }^{24}$.

Sasanuma, Ito \& Person (as cited in Harley 2001) report that the following types of dyslexia can be distinguished not only in alphabetic

23 Regional cerebral blood flow.

24 English is introduced to the curriculum in secondary school. As soon as English instruction is given, it may turn out that the child who has never had any reading problems in his mother tongue, suddenly starts to have problems with learning a foreign language. 


\section{Patrycja Dyszy-Chudzińska: Developmental Dyslexia vs. Japanese Writing Systems' Neuronal Processing}

languages, but also in Japanese: surface dyslexia, phonological dyslexia and deep dyslexia. The counterpart of surface dyslexia 25 is found in patients who suffer from the selective processing disorder of kanji characters, especially those with irregular character-to-sound correspondence. Nevertheless kana reading ability, including pseudowords (Tanemura 2006), does not sustain any loss (Wydell 2003). Fushimi (as cited in Kosaka \& Tsuzuki 2004: 105) reports that a counterpart of phonological dyslexia is found in the Japanese who can normally read kana and kanji, but not Japanese pseudowords. Sasanuma, Ito \& Person (as cited in Harley 2001) emphasize that one sees the symptoms analogous to deep dyslexia when kana reading is selectively disturbed, while kanji reading is still possible. In this type of dyslexia, mistakes appear in the kanji reading process caused by semantic and visual processing (Wydell 2003).

\section{The Neuronal Processes Underlying Developmental Dyslexia in Japanese}

Seki (Seki et al. 2001) conducted a neuroimaging test on Japanese dyslexic children while reading kana. The children examined showed distinctive activation of the following regions: the bilateral occipital cortex in two dyslexics, the inferior part of the frontal regions in two other dyslexics and both the bilateral occipital cortex and the inferior part of precentral gyrus in the remaining one. However, in all the control subjects, activation of the left middle temporal gyrus was detected. In the dyslexic children, the activation of the middle temporal gyrus was rather vague, so compensatory management processes for the unskilled reading ability of dyslexic children was assumed. Seki reports that these results were similar to the results of the previous test run on adult dyslexics using the Roman alphabet. The results suggest that the brain malfunction underlying dyslexia during the task of reading must be common despite differences in language (Seki et al. 2001:1). However, Seki did not examine the kanji reading process so his conclusion might not be completely accurate. The next neuroimaging studies run by Seki (et al. 2004) showed that the posterior parts of the superior temporal sulcus were active during auditory tasks. This indicates that phonological representations are manipulated in

\footnotetext{
25 Those terms are originally applied to acquired dyslexia but many researches also apply them also to developmental dyslexia. Castles (as cited in Harley 2001) defined two types of developmental dyslexia - phonological and surface dyslexia. In the first case, difficulties in phonological processing are to be observed. The visual image of a word is crucial to this type of dyslexia. Children recognize words well known to them without any major difficulties but have problem recognizing unknown and abstract words. The second type of dyslexia manifests in problems with reading exceptions. Here, children read mainly using a sound-letter correspondence based strategy to eventually grasp the meaning, though processing a sound form rather than a visual one. Often it is referred to as the delayed acquisition of reading abilities. There is also deep dyslexia, which is thought to be more complex and resistant to therapy (http://www.dysleksjaporadnik.org/?n=pages/ informacje1 [accessed: 16.04.2009]).
} 
this area. In contrast, the intraparietal sulci were active during the visual tasks, which may suggest that the phonemic manipulation of kana characters is visuospatial. At other times, increased activation within the left inferior frontal and parietal gyrus was detected. A similar pattern of activation was observed in the English letters rhyming test (Seki et al. 2006). Fujimaki and Kato (as cited in Ishii 2006) also remind us that decreased activation in the left speech area ${ }^{26}$ has been detected in rapid Japanese readers in the speed reading task and in Japanese dyslexic readers. However, Kato $(2003,2006)$ remains critical about the accuracy of the fMRI studies performed on Japanese children ${ }^{27}$.

The problem of a language independent, universal neural substrate underlying developmental dyslexia has been investigated by the application of advanced technology analysing the neuronal processing of writing systems. However, researches do not agree unanimously on this matter. The prevailing conviction in the professional journals is that the substrate underlying developmental dyslexia is common despite language differences, but that dyslexia can be manifested in various ways depending on the consistency of the grapheme-to-phoneme relationship in different languages (New Zealand's Ministry of Education ${ }^{28}$ ). In English speaking countries, it is believed that dyslexia is caused by the phonological deficit (Kosaka \& Tsuzuki 2004; Seki et al. 2006, 2008). Studies conducted in Beijing, Hong Kong and Taiwan suggest, that the phonological awareness deficits (New Zealand's Ministry of Education'29) and visual processing deficits (Zhang \& Popp ${ }^{\circ}$ ) may cause developmental dyslexia in Chinese. Similarly, studies suggest that, besides the phonological deficit (Uno et al. 2007) at the phoneme and mora level (Seki et al. 2006, 2008), a visual information processing deficit might be crucial to developmental dyslexia in the Japanese (Uno et al. 2002, 2007). Kato (2006) claims that the processes underlying dyslexia in the Japanese and English languages are basically the same. Japanese consists of visually-processed characters but, in spoken Japanese, as in English, phonological awareness plays an important role.

Bruck, Genesee, \& Caravolas (as cited in Kobayashi et al. 2005) suggest that differences in the transparency of written language lead to divergent patterns of reading acquisition and reading disabilities. Seki (et al. 2004) claims that, because of the phonological and orthographical

\footnotetext{
${ }^{26}$ Sanō no gengoya (左脳の言語野).

${ }_{27}$ The way Japanese is articulated hinders accurate reading when reading aloud is tested. What makes the situation even more complicated is that kanji's meaning can be grasped without applying the decoding process. Finally, a silent reading methodology has yet not been sufficiently standardized - too little data has been gathered (Kato 2003, 2006).

28 http://www.tki.org.nz/r/literacy_numeracy/pdf/literature-review.pdf [accessed: 15.03.2009]

29 http://www.tki.org.nz/r/literacy_numeracy/pdf/literature-review.pdf [accessed: 15.03.2009]

so http://www.wm.edu/education/599/o4projects/Zhang.pdf [accessed: 15.04.2009]
} 


\section{Patrycja Dyszy-Chudzińska: Developmental Dyslexia vs. Japanese Writing Systems' Neuronal Processing}

simplicity of the Japanese language, dyslexic children more easily master the correspondence between letters and sounds than children struggling to read alphabetic languages ${ }^{31}$. English, compared to other alphabetic languages like Italian or Spanish, is relatively complicated due to its inconsistent grapheme-to-phoneme correspondence and irregular orthography (Wydell 1999). Thus, to become a skilled reader in English, both a lexical (logographic) strategy and a sub-lexical (alphabetic) processing strategy are required. A reader also has to master a sub-syllabic processing strategy. This kind of sub-lexical and sub-syllabic phonological processing is not necessary, however, for reading both kana and kanji. It is implied that the phonological recoding process in kana is essentially at the level of syllables/moras rather than phonemes. Wydell and Morton (as cited in Wydell 1999) claim that kanji are primarily processed phonologically at the level of whole words. Kanji, unlike words in alphabetic languages, or even kana, are units resistant to further phonological segmentation. Additionally, phonological processing in kanji is relatively simple because of the more arbitrary relationship between sound and symbol. This can be accounted for by the fact that kanji are subject to lexical rather than sub-lexical processing, since children learn kanji essentially by rote, remembering whole characters as words (Wydell \& Kondo 2003).

Given all the above assumptions, Wydell (1999) suggests that it would be possible to find bilinguals with monolingual dyslexia. Cases of monolingual dyslexia have been reported in English/Italian (dyslexia in English), English/Dutch (dyslexia in English), English/Japanese (dyslexia in English), Dutch/Japanese (dyslexia in Dutch) bilinguals (Wydell \& Kondo 2003). Wydell and Butterworth (1999; Wydell 1999, 2000) examined AS, an English/Japanese bilingual boy, whose reading and writing difficulties are confined to English alone. According to Firth's (Wydell 1999: 299) reading model, dyslexic learners do not develop the ability to make quick and automatic links between letters and their sounds, becoming arrested at the logographic stage. Wydell supposes that this could be the case with AS - he became arrested at the logographic stage and did not/could not develop an alphabetic processing strategy. Thus, Wydell and Butterworth's hypothesis of granularity and transparency suggests that it would be possible to be an English/Japanese bilingual with monolingual dyslexia only in English alone, considering the differences between Japanese and English grammar. Wydell and Butterworth (Wydell 1999, 2000) suggest that there are no incidences of phonological dyslexia in kana and kanji - an idea Ziegler \& Goswami (2005) do not agree with. Most up-to-date studies show that Japanese

\footnotetext{
${ }^{31}$ Wydell and Butterworth (1999; Wydell 1999, 2000) have also been investigating that problem, proposing a 'hypothesis of granularity and transparency', which suggests that any language where the sound-symbol correspondence is regular or transparent, such as kana characters, or any language whose orthographic units represent sounds at the word level, such as kanji characters, will produce a lower incidence of reading difficulties related to phonological analysis.
} 
dyslexic children encounter the same phonological difficulties as dyslexics from other countries. They perform poorly in the syllable deletion, pseudoword repetition, RAN (rapid automatized naming; Kobayashi et al. 2003) tasks. Ziegler \& Goswami (2005) have reservations about the methodological side of the studies run by Wydell and Butterworth. They postulate that dyslexia is very much alike in all languages, but its exact manifestations in different languages might vary depending on the regularity/irregularity of the orthography in a given language. A more coarse orthography does not contribute to a reduced incidence of dyslexia, they claim (Ziegler \& Goswami 2005). Tan's (et al. 2004) neuroimaging studies suggest that reading English and Chinese produces divergent activation of the brain. Brain functioning, and indeed brain structure, is moulded by experience (Butterworth \& Tang 2004), meaning that learning shallow and regular orthographies (e.g. Italian, Finnish; Wydell 2000) does not affect brain the same way as learning Chinese (Butterworth \& Tang 2004) or Japanese (Nakamura et al. 2005). Tan revealed that decreased activation is exhibited in different brain areas in English and Chinese dyslexics during the reading process (Butterworth \& Tang 2004). Consequently, he concludes that the biological abnormality of developmental dyslexia is dependent on culture (Tan et al. 2004) and produces varied brain activation depending on the language. In contrast, Butterworth and Firth (Butterworth \& Tang 2004) claim that the phonological analysis deficit is the universal substrate underlying developmental dyslexia in all languages, though dyslexia's incidence rate would be higher if phonemes were involved.

\section{Conclusion}

In Japan, four different writing scripts are used for different purposes. The scripts are: kanji, hiragana and katakana (collectively called kana) and rōmaji. The reading process in Japanese is related more to syllable rather than phonemic manipulation. Written Japanese is a syllable-based language, while spoken Japanese is rather mora-based. In some words mora-units and syllable-units are the same.

Kanji, the logograms, are processed lexically, while kana is primarily processed phonologically. Kanji are mainly subject to visual recognition. Kana is phonologically coded, while kanji's coding is based on its visual pattern. An isolated kanji character is analyzed in the right hemisphere, but a sequence of characters undergoes neuronal processing in the left hemisphere. Similarly, phonograms, katakana and hiragana are processed in the left hemisphere.

The incidence rate of developmental dyslexia in Japan is lower compared to countries speaking alphabetic languages. This is explained by the peculiarity of the Japanese language. Unlike in alphabetic languages, the correspondence between phoneme and grapheme is very regular in 


\section{Patrycja Dyszy-Chudzińska: Developmental Dyslexia vs. Japanese Writing Systems' Neuronal Processing}

Japanese ${ }^{2}$. Developmental dyslexia has yet not been defined by law in Japan, therefore IDA's internationally established definition is employed. Since dyslexia is a developmental deficit, its symptoms may change over time.

It is argued that developmental dyslexia might be strongly coupled with a phonological deficit, both at the phoneme and the mora levels. However, in Japanese, a syllable awareness deficit could be the cause of dyslexia, rather than a phonological awareness deficit, since Japanese is based more on syllables than phonemes. A visual processing deficit should also not be underestimated when discussing dyslexia in this language.

The problem of the substrate underlying developmental dyslexia either common to all languages or language dependant - is also noteworthy. This matter is not without controversy among researches. The majority of researches does agree on the universal basis of developmental dyslexia but assumes various manifestations related to language regularity. For that reason, dyslexia is actually manifested in various ways in all the Japanese scripts, since kana and kanji are processed differently in the human brain.

Cases where dyslexia surfaced selectively during writing kanji, reading and writing kanji, reading and writing both kanji and katakana and reading and writing kana and kanji, have also been reported. Similarly to alphabetic languages, phonological processing plays a significant role in spoken Japanese. Kanji, however, are mainly visually processed. The type of developmental dyslexia that manifests itself only in the alphabetic language (e.g. in English/Japanese bilinguals or in Japanese children struggling to master an alphabetic language) has been also detected in Japanese. This monolingual dyslexia in an alphabetic language but not in Japanese could be triggered by irregular and insufficiently transparent orthography, which is phonemically manipulated. It could therefore be concluded that, if developmental dyslexia surfaces in the Japanese, it will manifest itself all the more in alphabetic languages.

The symptoms of developmental dyslexia in Japanese are similar to those in alphabetic languages. They are related to impaired phonological, visual and auditory processing and impaired fine and gross motor skills. Japanese children have considerable problems with reading and writing "special syllables" and kanji with irregular and multiple readings. A reading disability is often coupled with a writing disability. Kanji causes more reading and writing difficulties for Japanese children than kana.

Dyslexia is a developmental deficit that cannot be fully overcome with time. The learning process can be relatively facilitated, but mainly due to compensatory methods. Even if a child eventually manages to acquire reading skills, writing difficulties tend to persist over time.

\footnotetext{
${ }^{32}$ Of course, alphabetic languages also vary in the consistency of the sound-symbol relationship (e.g. English and Italian), so the above statement expresses a more general idea.
} 


\section{References}

Bogdanowicz, M., \& Andryjanek, A. (2004). Uczeń z dysleksją w szkole: poradnik nie tylko dla polonistów (Dyslexic child at school: a guide not only for Polish teachers). Gdynia: Wydaw. Pedagog. OPERON.

Butterworth, B., \& Tang, J. (2004). Dyslexia has a language barrier. The Guardian. Retrieved April 14, 2009 from http://education.guardian.co.uk/higher/research/story/o,,1310297,00.html

Cassin, B., \& Solomon, S. (1990). Dictionary of Eye Terminology. Gainsville, Florida: Triad Publishing Company.

Chmielina, A. (2005). Analiza fonetyczna wybranych nowych zapożyczeń w języku japońskim. (The phonetic analysis of selected new loanwords in Japanese; Unpublished master's degree thesis; The Institute of Linguistics, Adam Mickiewicz University in Poznan, Poland).

Harley, T. (2001). The psychology of language. From data to theory. Hove: Psychology Press.

Haruhara, K., Uno, A., Kaneko, M., Kaga, M., Matsuda, H. (2003). 特異的に言語 性意味理解力障害を呈する発達障害児 (A child with developmental disorders presenting specific linguistic meaning understanding ability disorder). In Uno, A. (Ed.), スクリーニング検査法の開発 (Development of screening test methods) (pp. 59-65). National Institute of Mental Health.

Hatta, T., Hirose, T. (1995). Reading disabilities in Japan: Implications from the Study of Hemisphere Functioning. In Taylor, I., \& Olson, D.R. (Ed.), Scripts and Literacy (pp. 231-247). Springer.

Ishii，K. (2006). 読み書きのみの学習困難（ディスレキシア）への対応策 (How to handle reading and writing learning difficulties (dyslexia)). National Institute of Science and Technology Policy, 45(1).

Itani, T., Uno, A., Kobayashi, M. (2001). かなに比べて漢字に強い読み書き障害を 示した一例(A child showing increased difficulties in reading and writing kanji compared to kana). 小児の精神と神経 (Psychiatria et neurologia paediatrica Japonica), 41 (2/3), 169-173.

Kaczmarek, B. (1998). Mózg, język, zachowanie (Brain, language and behaviour). Lublin: UMCS.

Kaneko, M., Haruhara, K., Uno, A., Kaga, M., Masayuki, S. (2003). 仮名読み書き 障害を呈する学習障害児の音読過程における眼球運動の軌跡 (Eye Movement Patterns during the Process of Word Reading in Developmentally Dyslexic Japanese Children). In Uno, A. (Ed.), スクリーニング検査法の開発 (Development of screening test methods) (pp. 39-45). National Institute of Mental Health.

Kato, J. (2006). The comment to the Japanese edition of 読み書き障害(ディスレ クシア)のすべて (Everything about developmental dyslexia) by Shaywitz, S. (2003). Overcoming Dyslexia. PHP 研究所, 155-159, 182-183, 220-228, 363366.

Kato, J., Hara, H., Azumi, Y., Ando, H. (2005). ディスレクシア児への各職種によ るチーム評価の実際 (Team Assessment and Teaching Approaches of a Boy Diagnosed with Dyslexia and Pervasive Developmental Disorder Not Otherwise Specified). Japanese Journal of Learning Disabilities, 14 (3), 336347.

Kato, J. (2003). 読夕書きの言語認知神経心理学と研究の動向一特集にあたってー 


\section{Patrycja Dyszy-Chudzińska: Developmental Dyslexia vs. Japanese Writing Systems' Neuronal Processing}

Cognitive neuropsycholinguistics and scientific trends in reading and writing). Journal of Learning Disabilities, 12(3), 240-247.

Kobayashi, M., Haynes, C., Hook, P., Kato, J. (2005). Effects of mora deletion, nonword repetition, rapid naming and visual search performance on beginning reading in Japanese. Annals of Dyslexia, 55(1), 105-128. Retrieved March 2, 2008, from http://findarticles.com/p/articles/mi_qa3809/is_200506/ai_n13644140/pg_1

Kobayashi, M.S., Kato, J., Haynes, Ch., Macaruso, P., Hook, P. (2003). 幼児の読 み能力に関わる認知言語的能力(The influence of cognitive-linguistic abilities on babies' reading abilities). Japanese Journal of Learning Disabilities, 12(3), 259-267.

Kosaka, D., Tsuzuki, S. (2004). 音韻認識の視点から学習障害児の読み書き指導を 考える (The reading and writing tuition of learning disables children from the perspective of onin recogniction). 治療教育学研究 (Japanese journal of medicopedagology), 24, 103-112.

Kubota，A. (2003). 学習障害児のアセスメントと教育指導について (On assessment and educational guidance of learning disabled children). Japanese Journal of Studies on Disability and Difficulty, 31(2), 161-168.

Lyon, G.R., Shaywitz, S.E., Shaywitz, B.A. (2003). Defining Dyslexia, Comorbidity, Teachers' Knowledge of Language and Reading. Annals of Dyslexia, 53, 1-14. Retrieved November 21, 2007, from http://findarticles.com/p/articles/mi_qa3809/is_200301/ai_n9226146/

Matsuda, M., Suzuki, N., Nagahama, Y., Okina, T., Hirakawa, K. (2006). 読多書 き障害の認知神経心理学一その貢献と弊害 (Cognitive neuropsychology on the disorders in written language with special reference to the differences between alphabetical languages and Japanese). シンポジウム : 失語症への認知神経心 理学的アプローチ (Symposium on Cognitive Neuropsychology's Approach to Aphasia), (141) 21.

Nakamura, K., Oga, T., Okada, T., Sadato, N., Takayama, Y., Wydell, T., Yonekura, Y., Fukuyama, H. (2005). Hemispheric asymmetry emerges at distinct parts of the occipitotemporal cortex for objects, logograms and phonograms: A functional MRI study. NeuroImage, 28(3), 521-528. Retrieved April 14, 2009, from http://www.brunel.ac.uk/3518/PDF//Wydell_Hemispheric\%20asymmetry\%20fMRI_Neuroimage5_MS.pdf

New Zealand's Ministry of Education. Literature Review: an International Perspective on Dyslexia. Retrieved March 15, 2009, from http://www.tki.org.nz/r/literacy_numeracy/pdf/literature-review.pdf

Oishi, N. (2001). 読み書き障害のリハビリテーション (Intervention for developmental dyslexia). 失語症研究 (Japanese Journal of Aphasia), 21(3) 1926.

Price, C. (2002). The functional anatomy of word comprehension and production. In Altman, G. (Ed.), (pp. 48-64), Psycholinguistics. London: Routledge.

Seki, A., Kassai, K., Uchiyama, H., Koeda, T. (2008). Reading ability and phonological awareness in Japanese children with dyslexia. Brain Development, 30(3). Retrieved April 2, 2009, from http://www.ncbi. nlm.nih.gov/pubmed/17720344

Seki, A., Kassai, K., Koeda, T. (2006). The reading ability and phonological awareness in Japanese dyslexic children. Neuropediatrics, 37. Retrieved April 
2, 2009, from http://www.thieme-connect.com/ejournals/abstract/neuropediatrics/doi/10.1055/s-2006-945694

Seki, A., Koeda, T., Okada, T., Sadato, N. (2004). The Approach to Developmental Dyslexia the Use of Functional MRI Studies. Journal of Japanese Society of Pediatric Radiology, 20(1). Retrieved April 2, 2009, from http://sciencelinks.jp/j-east/article/200407/000020040704Ao089970

Seki, A., Koeda, T., Sugihara, S., Kamba, M., Hirata, Y., Ogawa, T., Takeshita, K. (2001). A functional magnetic resonance imaging study during sentence reading in Japanese dyslexic children. Brain and Development, 23(5). Retrieved April 2, 2009, from http://www.sciencedirect.com/science?_ob=ArticleURL\&_udi=B6T5043PBMR17\&_user=10\&_rdoc=1\&_fmt=\&_orig $=$ search \&_sort $=\mathrm{d} \&$ view $=$ c\&_acct $=$ Cooo0 $50221 \& \_$version $=1 \& \_u r l V e r s i o n=0$ \&_userid=10\&md5=ec353d53259964783feb26ab734d47ea

Shinagawa, Y. (2003). 总けてなんかない (Don’t idle away)! Tokio: Iwasaki Shoten.

Tan, L.H., Siok, W.T., Perfetti, Ch.A., Jin, Z. (2004). Biological abnormality of impaired reading is constrained by culture. Nature, 431. Retrieved April 4, 2009, from http://www.nature.com/nature/journal/v431/n7004/full/ natureo2865.html

Tanemura, J. (2006). 読み書き障害の認知神経心理学的分析 (Cognitiveneuropsycholinguistic analysis of the reading and writing disorder). Japanese Journal of Cognitive Neuroscience, 8(1), 16-21.

Taylor, I. (1987). Psychology of literacy: East and west. In Kerckhove, D. De, \& Lumsden Ch. J. (Ed.), The alphabet and the brain (pp. 202-234). Berlin: Springer.

Tubielewicz, J. (1996). Kultura Japonii. Słownik (The dictionary of Japanese culture). Warszawa: Wydawnictwo Szkole i Pedagogiczne.

Uno, A., Haruhara, N., Kaneko, M., Awaya, N. (2007). 発達性 dyslexia の認知障 害構造一音韻障害単独説で日本語話者の発達性dyslexia を説明可能なのか? (Cognitive Dysfunction in Developmental Dyslexia - Can Developmental Dyslexia in Japanese be Interpreted as a Simple Phonological Disorder?). Jpn. J. Logop. Phoniatr., 48, 105-111.

Uno, A., Haruhara, N., Kaneko, M., Wydell, T.N. (2006). 小学生の読み書きスク リーニング検查(Screening Test of Reading and Writing for Japanese Primary School Children (STRAW)). Tokyo: Intern.

Uno, A. (2006). 神経学的要因による読み書き困難に対する多方面からの支援 (Multifarious support to reading and writing difficulties caused by neurological factors). Tokio: Ministry of Education, Culture, Sports, Science and Technology, National Institute of Science and Technology Policy, Science and Technology Trends Research Centre, 25-49.

Uno, A., Haruhara, K., Kaneko, M. (2005). 発達性読み書き障害への訓練と訓練効 果ーバイパス法ー (Training towards developmental dyslexia and its results the bypass method). Advances in the Medicine on Developmental Disabilities, $17,35-47$.

Uno, A. (2003a). 学習障害児への支援のあり方ー理解とアプローチー (The actual state of support towards learning disabled children - sympathy and approach). In Uno, A. (Ed.), スクリーニング検査法の開発 (Development of screening test methods) (pp. 79-84). National Institute of Mental Health.

Uno, A. (2003b). 病像と診断一特異的書字障害の診断と治療 (The clinical picture 


\section{Patrycja Dyszy-Chudzińska: Developmental Dyslexia vs. Japanese Writing Systems' Neuronal Processing}

and diagnosis - diagnosis and treatment of a specific writing disability). In Uno, A. (Ed.), スクリーニング検査法の開発 (Development of screening test methods) (pp. 67-72). National Institute of Mental Health.

Uno A., Kaneko M., Haruhara N., Matsuda H., Kato M., Kasahara M. (2002). 発 達性読み書き障害: 神経心理学的および認知神経心理学的分析 (Developmental dyslexia: neuropsychological and cognitiveneuropsychological analysis). Higher Brain Function Research, vol. 22, no. 2, s. 44-50.

Wydell, T.N., \& Kondo, T. (2003). Phonological deficit and the reliance in orthographic approximation for reading: a follow-up study on an EnglishJapanese bilingual with monolingual dyslexia. Journal of Research in Reading, 26(1), 33-48.

Wydell, T.N., \& Butterworth, B. (1999). A case study of an English-Japanese bilingual with monolingual dyslexia. Cognition, 70, 273-305.

Wydell, T.N. (2003). 言語・認知神経心理学における読みについて(On the reading process in cognitive neuropsycholinguistics). Japanese Journal of Learning Disabilities, 12(3), 248-256.

Wydell, T.N. (2000). Neuronal Processes involved in reading: A cross-linguistic study with brain imaging techniques. Technical Research Reports of the Institute of Electronics, Information and Communication Engineers, 100(336), 17-23.

Wydell, T.N. (1999). Developmental Dyslexia: A cross-linguistic comparison between English and Japanese. Technical Research Reports of the Institute of Electronics, Information and Communication Engineers, 99(237), 57-64.

Ziegler, J.C., Goswami, U. (2005). Reading Acquisition, Developmental Dyslexia, and Skilled Reading Across Languages: A Psycholinguistic Grain Size Theory. Psychological Bulletin, 131 (1), 3-29.

Zhang, J., Popp, P. Dyslexia in Chinese Running head: DYSLEXIA IN CHINESE AND ENGLISH. Retrieved April 15, 2009, from http://www. wm.edu/education/599/o4projects/Zhang.pdf 